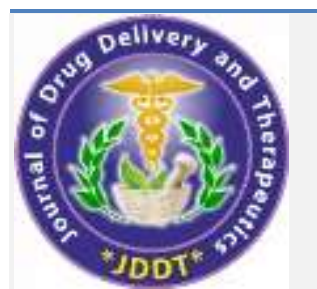

\section{Journal of Drug Delivery and Therapeutics}

Open Access to Pharmaceutical and Medical Research

Copyright (c) 2022 The Author(s): This is an open-access article distributed under the terms of the CC BY-NC 4.0 which permits unrestricted use, distribution, and reproduction in any medium for non-commercial use provided the original author and source are credited

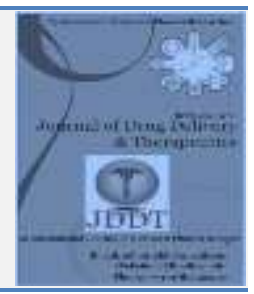

Research Article

\title{
Formulation and Evaluation of Enteric Coated Matrix Tablets of Mesalamine for Inflammatory Bowel Disease
}

\author{
Nikita Chourey ${ }^{1}$, Khushi Chouksey2* \\ ${ }^{1}$ Truba Institute of Pharmacy, Karond-Gandhi Nagar Bypass Road, Bhopal, 462038 \\ ${ }^{2}$ Sagar Institute of Pharmacy and Technology (SIPTec), Opposite International Airport, Gandhi Nagar Bhopal (M.P.) 462036
}

\section{Article Info:}

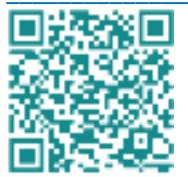

\section{Article History:}

Received 11 November 2021 Reviewed 20 December 2021 Accepted 28 December 2021 Published 15 January 2022

\section{Cite this article as:}

Chourey N, Chouksey K, Formulation and Evaluation of Enteric Coated Matrix Tablets of Mesalamine for Inflammatory Bowel Disease, Journal of Drug Delivery and Therapeutics. 2022; 12(1):56-61

DOI: http://dx.doi.org/10.22270/jddt.v12i1.5176

\section{*Address for Correspondence:}

Khushi Chouksey, Sagar Institute of Pharmacy and Technology (SIPTec), Opposite International Airport Gandhi Nagar Bhopal (M.P.) 462036

\begin{abstract}
Mesalamine is a gold standard anti-inflammatory drug used to treat inflammatory bowel illnesses. It's usually used to treat and keep Ulcerative Colitis in remission in mild to moderate cases. Mesalamine is rapidly cleared from circulation after being consumed orally, with an elimination half-life of only one hour. Oral intake of delayed or slow released matrix formulations can acquire therapeutic concentration in the intestines. The goal of this study was to use guar gum as a carrier to develop colon-specific delivery methods for mesalamine. The matrix tablets were made using the direct compression process, which is today regarded as a cost-effective and straightforward manufacturing method. Dip coating was used to coat the tablets with varied concentrations of Eudragit L100 polymer. Tablets were studied in vitro in a variety of dissolution solutions, including $0.1 \mathrm{~N} \mathrm{HCl} \mathrm{(pH} \mathrm{1.2),} \mathrm{phosphate}$ buffers pH 6.8 and 7.4, and others. The optimized formulation was subjected to swelling tests. All of the formulations' physicochemical parameters were confirmed to be in line with pharmacopoeial norms. All formulations were subjected to stability tests in accordance with ICH recommendations. The tablets coated with Eudragit L100 (20 percent w/v) had a sustained release of 78.39 percent over 12 hours, while the uncoated tablets released the medication in 9 hours. Tablet stability tests revealed that under accelerated and room temperature storage settings for 6 months, there was reduced degradation. In the colon, the enteric-coated Eudragit L100 coated matrix tablets of mesalamine demonstrated promising site-specific drug delivery.
\end{abstract}

Keywords: Mesalamine, Guar gum, Eudragit L100, Direct compression, Inflammatory bowel illnesses

\section{INTRODUCTION}

The importance of pharmaceuticals that are specifically absorbed from the colon region has mostly been supplied by the colon specific drug delivery system, which prevents degradation in the upper gastrointestinal tract (GIT). The release of drugs at this location will assure the greatest therapeutic benefit1-3. Colon-targeted delivery systems are useful for treating localised colonic disorders such as Crohn's disease, ulcerative colitis, and constipation, which are best addressed by drug delivery to the colon ${ }^{4}$. The medicine should be protected from absorption in the stomach and small intestine by the colon-specific delivery system, preventing a fast commencement of drug release upon entering the colon's less hostile environment. To deliver antiinflammatory agents to the sites of inflammation, various drug delivery approaches have been developed, including $\mathrm{pH}$-sensitive system, time-dependent system, pro-drugs, and microflora-activated system, and thus systemic drug absorption should be reduced, as this leads to unwanted systemic side effects ${ }^{5-7}$. The pH-sensitive system and the time-dependent system are the most commonly utilised systems for colon-specific medication delivery-10. Polysaccharides are monosaccharide polymers with a variety of qualities. They are cheap and come in a variety of forms. Several polysaccharides, such as chitosan, pectin, chondroitin sulphate, cyclodextrins, dextrans, and guar gum $^{11}$, have already been tested for their potential as colonspecific drug carrier systems. These natural polymers have a lot of potential as a drug delivery technology that is really colon-specific and commercially available. The reason for this is that they are nontoxic and simple to work with, and the FDA is likely to accept them for medicinal formulations ${ }^{12}$. Polysaccharides are employed in dosage forms as prodrugs, matrix systems, and dry coatings by direct tableting and/or standard coating agents ${ }^{13}$ for colonic delivery. Guar gum is a non-ionic polysaccharide made up of linear chains of (1-4)-bD-mannapyranosyl units linked by 1-6 links to a-Dgalactopyranosyl units. Guar gum is employed as a binder, disintegrant, suspending agent, thickening agent, and stabilising ingredient in pharmaceutical formulations ${ }^{14}$. In cold water, guar gum hydrates and swells, generating viscous colloidal dispersions or sols. As a result, it's employed as a gelling agent to slow down the release of drugs from tablets ${ }^{15}$. Due to its biodegradability with colonic enzymes, the potential use of guar gum as a polymer for colon-specific dosage forms has recently been examined. Various medications have been manufactured in matrix or 
compression coated tablets containing guar gum for this purpose. Methacrylic acid polymers, such as Eudragit L100, are $\mathrm{pH}$-dependent coating polymers that are utilised to coat solid dosage forms because they solubilize at $\mathrm{pH}$ 7. The main goal was to create a single coating layer that would inhibit medication release in the stomach or small intestine while also slowing drug release in the target region (colon) 16,17 . Mesalamine, the active component of Sulphasalazine, is available in specifically formulated oral and rectal forms for the treatment of mild to moderately active ulcerative colitis, as well as maintenance therapy during disease remissions. Pure mesalamine is rapidly and virtually completely absorbed whether administered directly in the proximal region of the small intestines or orally as a typical tablet, with minimal medication reaching the distal small intestine and colon ${ }^{18}$. As a result, enteric coated tablets or colonspecific dose forms can be used to prevent early absorption of mesalamine. Orally administered delayed-release mesalamine operates locally in the inflamed intestinal lumen and is partially absorbed into the systemic circulation. Because mesalamine's efficacy in IBD treatment is related to local action, the site of release and allowing for low systemic absorption, which is meant to limit the incidence of systemic side effects, are the most significant features for its therapeutic application ${ }^{19}$. Matrix tablets are affordable and straightforward to make with traditional tableting equipment, and their formulation has fewer processing variables. Several model medications have been used to study guar gum in the form of matrix tablets. As a result, the goal of this research was to create a colon-specific matrix tablet of mesalamine including the natural polysaccharide guar gum.

\section{MATERIALS AND METHODS}

\section{Materials}

Mesalamine was procured from Dr. Reddy's Laboratory, Hyderabad, India. Gaur gum was obtained from Central Drug House (CDR), Delhi. Microcrystalline cellulose, starch, talc was purchased from Loba chem Pvt. Ltd., Mumbai (India) and magnesium stearate was purchased from Moly chem. Mumbai (India). All other solvents and reagents were purchased from Merck (Germany) and were of analytical grade.

\section{Methods}

\section{Preformulation studies}

\section{Preparation calibration curve of mesalamine}

To make $(1000 \mu \mathrm{g} / \mathrm{ml})$ standard stock solution, $100 \mathrm{mg}$ of medication was carefully weighed and diluted in $100 \mathrm{ml} 0.1 \mathrm{~N}$ $\mathrm{HCl}(1.2 \mathrm{pH})$ in a $100 \mathrm{ml}$ volumetric flask (1). Then $10 \mathrm{ml}$ of stock solution (1) was placed in another $100 \mathrm{ml}$ volumetric flask to make $(100 \mu \mathrm{g} / \mathrm{ml})$ standard stock solution (2), then $1,2,3,4,5,6$, and $7 \mathrm{ml}$ of stock solution (2) was placed in another $10 \mathrm{ml}$ volumetric flask, and final concentrations of $10,20,30,40,50,60$, and $70 \mu \mathrm{g} / \mathrm{ml}$ were prepared with $0.1 \mathrm{~N}$ $\mathrm{HCl}(1.2 \mathrm{pH})$. The absorbance of the standard solution was measured at $232.5 \mathrm{~nm}$ with a UV/VIS spectrophotometer (UV-1700 Shimadzu, Japan). The square of the correlation coefficient (r2), which was derived by least-square linear regression analysis, was used to examine the linearity of the standard curve.

\section{Drug-excipients compatibility study}

To confirm the compatibility of medicines and excipients, FTIR spectra of pure drugs, polymers employed, and mixes were recorded on $\mathrm{KBr}$ disc technique using Brukers Alpha Spectrophotometer with IR solution software. In a glass mortar and pestle, sample powder was completely mixed with potassium bromide before being compacted into discs in a hydraulic press (Techno search Instruments, India). All of the samples' FTIR spectra were acquired using 20 scans with a resolution of $4 \mathrm{~cm}-1$ throughout a spectral range of 4700 to $400 \mathrm{~cm}-1$.

\section{Pre compression evaluation}

Angle of repose, bulk density, tapped density, Carr's index, and Hausner's ratio were used to analyze the flow and compressibility qualities of a powder mixture.

\section{Angle of repose $(\theta)$}

The fixed funnel method was used to determine the angle of repose. Drug physical mixtures with various excipients were made, and the precisely weighed drug powder or physical combination was placed in a funnel. The height of the funnel was modified such that the tip of the funnel just touches the top of the medication powder heap. The powder was allowed to freely flow out of the funnel onto the surface. The following equation was used to compute the angle of repose.

$$
\theta=\tan -1(\mathrm{~h} / \mathrm{r})
$$

Where, $\mathrm{h}$ and $\mathrm{r}$ are the height and radius of the powder cone respectively.

\section{Bulk density}

The following formulas were used to calculate both the loose bulk density (LBD) and the tapped density (TBD).

$$
\text { LBD = Powder weight/volume of the packing }
$$

TBD = Powder weight /tapped volume of the packing

\section{Compressibility index}

The compressibility index of the granules was determined by Carr's compressibility index.

$$
\text { Carr's index }(\%)=[(\mathrm{TBD}-\mathrm{LBD}) / \mathrm{TBD}] \times 100 \text {. }
$$

\section{Hausner's ratio}

Hausner's ratio is a measure of how easy it is to measure powder flow. The following formula 20,21 was used to calculate it.

$$
\text { Hausner's ratio }=\text { Tapped density } / \text { Bulk density } \text {. }
$$

\section{Preparation of the matrix tablets}

Direct compression was used to make several tablet batch formulas (F1-F5). In a mortar and pestle, pure medicine (Mesalamine) and polymers (Gaur gum) were put through \#40 sieves and combined well for 10 minutes. After passing through \#40 sieves, lactose (diluent) was added to this mixture and thoroughly mixed for 5 minutes. After passing through \#60 sieves, this powder blend was lubricated with enough magnesium stearate and talc, and then directly compressed into tablets using a single punch rotary tablet machine (Rimek tablet mini press, Ahmadabad) with $10 \mathrm{~mm}$ flat punches. Table 1 lists the ingredients in the formulation. 
Table 1: Composition of matrix tablet of mesalamine

\begin{tabular}{|c|c|c|c|c|c|c|}
\hline S. No. & Ingredients & F1 & F2 & F3 & F4 & F5 \\
\hline 1 & Mesalamine & 250 & 250 & 250 & 250 & 250 \\
\hline 2 & Gaur Gum & 75 & 50 & 37.5 & 25 & 12.5 \\
\hline 3 & Microcrystalline Cellulose & 22.5 & 47.5 & 60 & 73 & 85 \\
\hline 4 & Starch (10\%) & 25 & 25 & 25 & 25 & 5 \\
\hline 5 & Talc & 5 & 5 & 5 & 2.5 & 2.5 \\
\hline 6 & Magnesium Stearate & 2.5 & 2.5 & 2.5 & 380 & 380 \\
\hline 7 & Total & 380 & 380 & 380 & & \\
\hline
\end{tabular}

\section{Enteric coating of the matrix tablets}

The Eudragit L100 solution was then applied to the mesalamine matrix tablets. In a mixture of ethanol, polyethylene glycol 400 ( 5 percent $\mathrm{w} / \mathrm{v}$ ), and water, different concentrations of Eudragit L100 coating solution (5 percent, 10 percent, and 20 percent $\mathrm{w} / \mathrm{v}$ ) were created (1:1). The matrix tablets were coated using a dip coating technique after being immersed in the coating solution.

\section{Post-compression parameters}

\section{Shape of tablet}

The form of the tablet was evaluated under a magnifying lens on directly compressed tablets.

\section{Thickness}

Twenty tablets were randomly selected from the representative sample and their thickness was measured using a digital vernier caliper $22-25$.

\section{Hardness}

The Monsanto hardness tester was used to determine the hardness of the tablets. Six pills from each batch were tested for hardness, with an average of six results and standard deviations recorded.

\section{Friability test}

Ten pills were carefully weighed and placed in the friability test instrument from each batch (Roche friabilator). The apparatus was rotated at $25 \mathrm{rpm}$ for 4 minutes while tablets were observed. After 100 rotations, the tablets were removed, dusted, and reweighed. The percentage weight loss was used to calculate the friability.

$$
\% \text { Friability }=(\mathrm{W} 1-\mathrm{W} 2) \times 100 / \mathrm{W} 1
$$

Where $\mathrm{W} 1=$ Initial weight of the 10 tablets, $\mathrm{W} 2=$ Final weight of the 10 tablets after testing.

Friability ratings of less than 0.5-1 percent are usually considered acceptable.

\section{Weight variation test}

Weight fluctuation is being investigated. Using an electronic balance, the individual weights (WI) of 20 tablets from each formulation were recorded. It was determined what their average weight (WA) was. The following is how the percent weight variance was computed. The average weights of the tablets were computed, as well as their standard deviations.

\section{Drug content}

Five tablets from each formulation were triturated with a mortar and pestle to determine drug content. In a $100 \mathrm{ml}$ volumetric flask, a properly weighed powder equivalent to
$250 \mathrm{mg}$ of medicine was diluted with enough phosphate buffer of pH 6.8 to reach the desired concentration. After that, the material was filtered and sonicated for 1 hour. A suitable sample of the filtrate was diluted and spectrophotometrically examined at $331.60 \mathrm{~nm}$ against a blank. The test was performed three times and the average drug content was calculated.

\section{Determination of swelling index}

The swelling was calculated as a percentage of the tablet's weight gain. All formulations' swelling behaviour was investigated. In a Petri dish containing 6.8 phosphate buffers, one tablet from each formulation was retained. The tablet was removed after 1 hour, soaked in tissue paper, and weighted. The weight of the tablet was then recorded every 2 hours, and the practice was repeated until the entire 16-hour period had passed. The tablet's percent weight gain was determined using a formula;

$$
\mathrm{S} . \mathrm{I}=\{(\mathrm{Mt}-\mathrm{Mo}) / \mathrm{Mo}\} \mathrm{X} 100
$$

Where, S.I = swelling index, Mt = weight of the tablet at time's and Mo $=$ weight of tablet at time $t=0$.

\section{In-vitro dissolution studies}

The USP Type I Apparatus (Paddle type) was used to conduct an in-vitro dissolution study in $0.1 \mathrm{~N} \mathrm{HCl}$ at $100 \mathrm{rpm}$ for 2 hours $(900 \mathrm{ml})$. The dissolution media was then changed with pH 7.4 phosphate buffer $(900 \mathrm{ml})$ and the system was evaluated for 3 hours, as the average small intestine transit time is 3 hours. The dissolution medium was replaced with pH 6.8 phosphate buffer after 5 hours and the results were examined for another 7 hours. Ten millilitres of the sample were taken at the conclusion of the time period and examined for mesalamine concentration. After each sample pullout, a $10 \mathrm{ml}$ fresh and filtered dissolving medium (buffers) was added to make the volume.

\section{RESULTS AND DISCUSSION}

Mesalamine was soluble in methanol and ethanol and was freely soluble in water. Mesalamine had a melting point of $280-282 \mathrm{oC}$ and a pH of 7.2 , respectively. At $\mathrm{pH} 7.2$, the partition coefficient and loss on drying of mesalamine were determined to be 11.7 and 8\%, respectively. Using a UV spectrophotometer (UV-1700 Shimadzu, Japan) in the linearity range $10-50 \mathrm{~g} / \mathrm{ml}$, the maximum of mesalamine was found to be $232.5,329.5$, and $331 \mathrm{~nm}$ in $0.1 \mathrm{~N} \mathrm{HCl}$, phosphate buffers $\mathrm{pH} 6.8$ and $\mathrm{pH} 7.4$ respectively. Fig.1. FTIR spectroscopy was used to identify mesalamine in relation to a marker component. As per the specification, it was recognized from the IR spectrum result. Fig.2. Various precompression parameters were applied to the tablet powder blend. Table No. 2 The powder blend's angle of repose values indicate that it has good flow properties. All of the 
formulations had bulk densities ranging from 0.3120 .005 to $0.3480 .016(\mathrm{gm} / \mathrm{ml})$, indicating that the powder had good flow qualities. All of the formulations' tapped density was determined to be between 0.5020 .007 and 0.5650.005, indicating that the powder has good flow qualities. All of the formulations had compressibility indices ranging from 31.271.27 to 44.600.26, indicating that the powder had good flow qualities. The Hauser's ratio in all of the formulations ranged from 1.150 .02 to 1.200 .10 , showing that the powder has good flow qualities. Table 3 shows the findings of postcompression parameters such as weight uniformity, hardness, thickness, friability, swelling index, and tablet disintegration time. All of the tablets from different batches met the required weight uniformity requirements. The matrix tablets had a hardness range of 50.08 to $6.60 .21 \mathrm{~kg} / \mathrm{cm} 2$ and a friability of less than 0.7 percent, indicating that they were compact and hard. The tablets' thickness ranged from $4.020 .32 \mathrm{~mm}$ to $4.350 .05 \mathrm{~mm}$. All of the formulations met the medication's content requirements, containing between $2420.18 \%$ and $2580.04 \%$ mesalamine, with good drug content uniformity. As a result, all of the physical characteristics of the prepared tablets were found to be virtually under control. The tablets were tested for in vitro dissolving for 12 hours in various dissolution solutions (pH 1.2, 6.8, 7.4). The results of the optimised formulation F5 showed that at the end of 12 hours, the drug release was at its maximum, 91.42 percent. Table 4 displays the results of formulation release studies. As a result, F5 was selected and coated with inner and outer coating materials before being evaluated for further research. The weight variation, thickness, hardness, friability, and medication content of tablets of various formulations with coating were exposed to various evaluation tests. The findings of the physicochemical examination of all batches of mesalamine coated matrix tablets are provided in Table 5. In-vitro drug release experiments in various gastric and intestinal fluids revealed that the coated formulations were gastro resistant for 2 hours at $\mathrm{pH} 1.2$ and 3 hours at $\mathrm{pH} 7.4$, releasing less than $10 \%$ of the medication (Fig. 3).

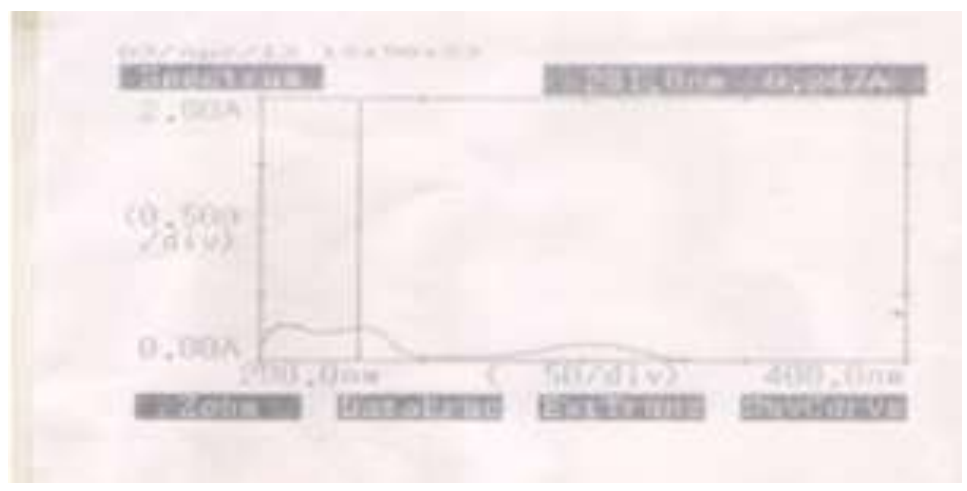

Figure 1: UV spectra of curve of mesalamine in $0.1 \mathrm{~N} \mathrm{HCl}$

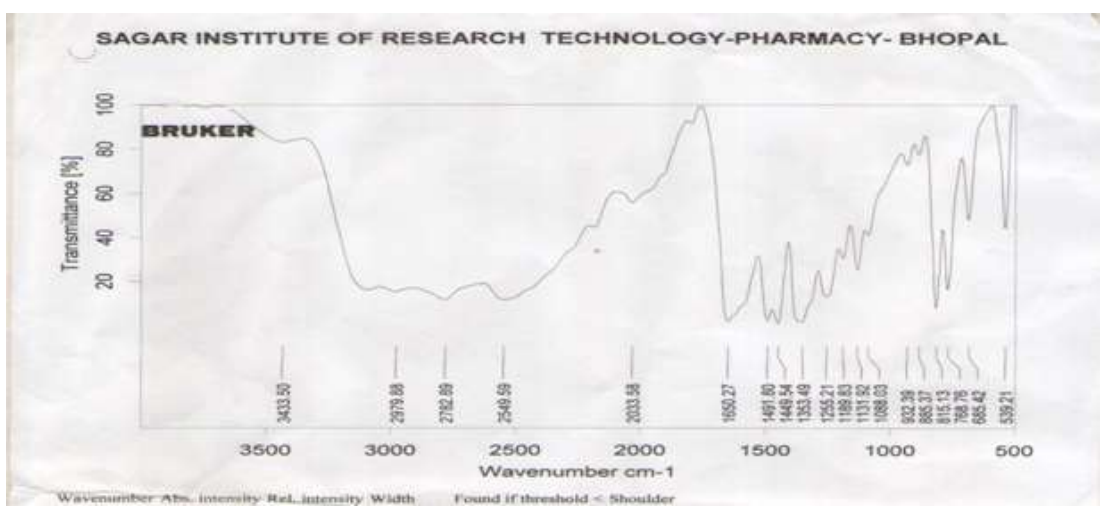

(A)

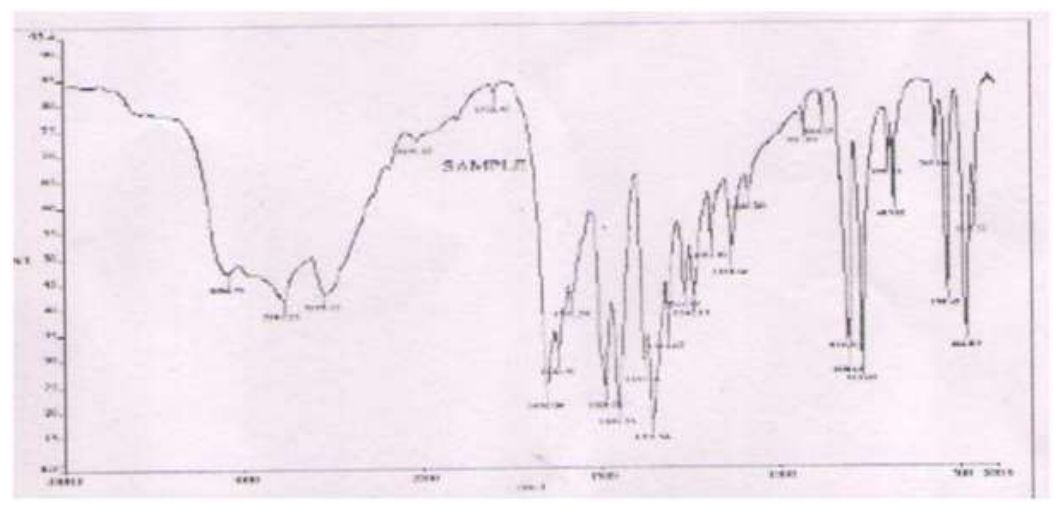

(B)

Figure 2: IR spectrum of (A) pure drug mesalamine (B) Drug+ Gaur gum 
Table 2: Result of pre-compression properties of mesalamine matrix tablets

\begin{tabular}{|c|c|c|c|c|c|}
\hline Formulations & $\begin{array}{l}\text { Bulk Density } \\
(\mathrm{g} / \mathrm{ml})^{*}( \pm \mathrm{SD})\end{array}$ & $\begin{array}{l}\text { Tapped Density } \\
(\mathrm{g} / \mathrm{ml}) *( \pm \mathrm{SD})\end{array}$ & $\begin{array}{c}\text { Compressibility Index } \\
(\%)^{*} \quad( \pm \text { SD) }\end{array}$ & $\begin{array}{c}\text { Angle of } \\
\text { Repose* }^{*} \\
( \pm \text { SD) }\end{array}$ & $\begin{array}{c}\text { Hauser's } \\
\text { ratio }\end{array}$ \\
\hline F1 & $0.345 \pm 0.025$ & $0.502 \pm 0.007$ & $31.27 \pm 1.27$ & $20.30 \pm 0.22$ & $1.18 \pm 0.01$ \\
\hline F2 & $0.312 \pm 0.005$ & $0.562 \pm 0.002$ & $44.48 \pm 0.20$ & $22.78 \pm 0.08$ & $1.19 \pm 0.01$ \\
\hline F3 & $0.348 \pm 0.016$ & $0.507 \pm 0.009$ & $31.36 \pm 0.17$ & $20.80 \pm 1.47$ & $1.15 \pm 0.02$ \\
\hline F4 & $0.313 \pm 0.020$ & $0.565 \pm 0.005$ & $44.60 \pm 0.26$ & $24.22 \pm 0.46$ & $1.20 \pm 0.10$ \\
\hline F5 & $0.313 \pm 0.025$ & $0.513 \pm 0.002$ & $38.98 \pm 0.02$ & $23.26 \pm 0.05$ & $1.16 \pm 0.02$ \\
\hline
\end{tabular}

Table 3: Results of post compression properties of mesalamine matrix tablets

\begin{tabular}{|c|c|c|c|c|c|c|}
\hline Formulation & $\begin{array}{c}\text { Thickness } \\
\mathbf{\pm} \mathbf{S D}^{*}(\mathbf{m m})\end{array}$ & $\begin{array}{c}\text { Hardness } \\
\mathbf{( k g} / \mathbf{c m} \mathbf{)} \mathbf{\pm} \mathbf{S D}^{*}\end{array}$ & $\begin{array}{c}\text { Friability } \\
\mathbf{( \% )} \pm \mathbf{S D}\end{array}$ & $\begin{array}{c}\text { Weight Uniformity } \\
\mathbf{( m g )} \pm \mathbf{S D}\end{array}$ & $\begin{array}{c}\text { Uniformity of } \\
\text { content } \pm \mathbf{S D}^{*}\end{array}$ & $\begin{array}{c}\text { Swelling } \\
\text { Index }\end{array}$ \\
\hline F1 & $4.06 \pm 0.025$ & $6.6 \pm 0.21$ & $0.62 \pm 0.01$ & $0.377 \pm 0.45$ & $258 \pm 0.04$ & 62.3 \\
\hline F2 & $4.35 \pm 0.05$ & $5 \pm 0.48$ & $0.66 \pm 0.25$ & $0.378 \pm 0.24$ & $242 \pm 0.18$ & 59.4 \\
\hline F3 & $4.12 \pm 0.12$ & $5 \pm 0.02$ & $0.64 \pm 0.54$ & $0.378 \pm 0.63$ & $248 \pm 0.02$ & 54.2 \\
\hline F4 & $4.02 \pm 0.32$ & $6 \pm 0.25$ & $0.59 \pm 0.62$ & $0.380 \pm 0.17$ & $251 \pm 0.033$ & 47.2 \\
\hline F5 & $4.32 \pm 0.04$ & $5 \pm 0.08$ & $0.59 \pm 0.88$ & $0.378 \pm 0.05$ & $249 \pm 0.014$ & 41.7 \\
\hline
\end{tabular}

All value are mean $\pm S D, n=3$

Table 4: In-vitro drug release data for formulation F1-F5

\begin{tabular}{|c|c|c|c|c|c|}
\hline \multirow{2}{*}{$\begin{array}{l}\text { Time } \\
\text { (hrs) }\end{array}$} & \multicolumn{5}{|c|}{ \% Drug Release } \\
\hline & F1 & F2 & F3 & $\mathrm{F} 4$ & F5 \\
\hline 1 & 7.33 & 8.8 & 9.0 & 9.43 & 10.81 \\
\hline 2 & 12.46 & 11.7 & 16.22 & 19.86 & 21.53 \\
\hline 3 & 16.70 & 16.8 & 21.6 & 28.82 & 29.62 \\
\hline 4 & 21.32 & 22.5 & 28.54 & 32.41 & 34.60 \\
\hline 5 & 24 & 26.41 & 34.66 & 38.55 & 40.34 \\
\hline 6 & 26.2 & 29.11 & 39.70 & 45.20 & 48.91 \\
\hline 7 & 30.2 & 32.8 & 45.90 & 49.87 & 55.40 \\
\hline 8 & 35.42 & 36.92 & 48.13 & 53.61 & 62.53 \\
\hline 9 & 38.1 & 42.53 & 51.93 & 58.33 & 74.33 \\
\hline 10 & 41.55 & 46.88 & 54.47 & 66.28 & 82.58 \\
\hline 11 & 45.21 & 51.64 & 59.33 & 71.54 & 86.22 \\
\hline 12 & 46.39. & 54.76 & 62.11 & 75.87 & 91.42 \\
\hline
\end{tabular}

Table 5: Evaluation of enteric coated tablets of mesalamine

\begin{tabular}{|c|c|c|c|}
\hline Parameters & E1 & E2 & E3 \\
\hline Hardness & $6.26 \pm 0.025$ & $6.31 \pm 0.06$ & $7.12 \pm 0.02$ \\
\hline Thickness & $6.84 \pm 0.2$ & $7.03 \pm 0.008$ & $0.54 \pm 0.44$ \\
\hline Friability & $0.58 \pm 0.6$ & $0.56 \pm 1.12$ & $812 \pm 0.21$ \\
\hline Weight variation & $383 \pm 0.32$ & $388 \pm 0.16$ & Not disintegrated \\
\hline Disintegration time (min) (in pH 1.2) & 30 & 40 & 10 \\
\hline Disintegration time (min) pH 6.8 & 4 & 7 & \\
\hline
\end{tabular}




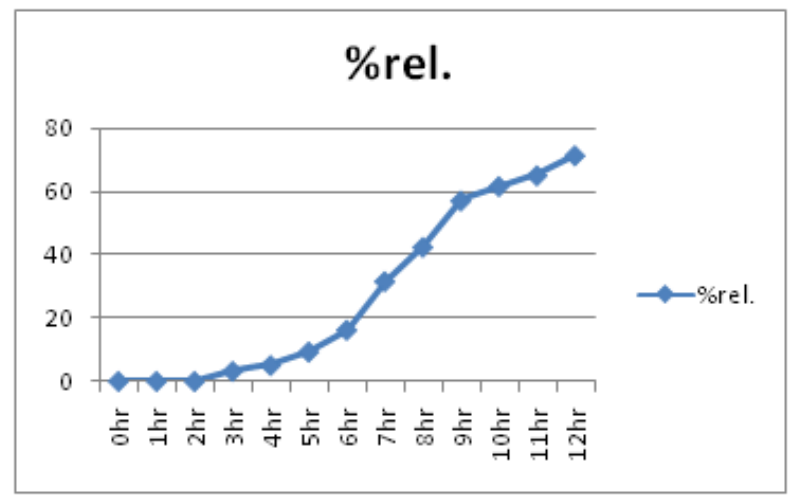

Figure 3: in-vitro drug release studies of optimized coated tablet

\section{CONCLUSION}

Wet granulation can be replaced with direct compression methods because it is a more straightforward, simplified, and cost-effective method of tablet production. There are several research articles available that show that direct compression is the preferred method of tableting. In vitro drug release experiments have shown that guar gum, in the form of matrix tablets, can prevent the medication from being released in the upper GI tract, i.e. the stomach and small intestine. Mesalamine guar gum matrix tablet formulations could be a promising technique for treating inflammatory bowel disease and other colon diseases. In addition, an in-vivo and pharmacokinetic research must be completed.

\section{REFERENCES}

1. Ashford M, Fell JT. Targeting drugs to the colon: delivery systems for oral administration. J Drug Target 1994; 2:241-57. https://doi.org/10.3109/10611869408996806

2. Rubinstein A. Approaches and opportunities in colon-specific drug delivery. Crit Rev Ther Drug Carrier Syst 1995; 12:101-49. https://doi.org/10.1615/CritRevTherDrugCarrierSyst.v12.i23.10

3. Watts PJ, Lllum L. Colonic Drug Delivery. Drug Dev Ind Pharm 1997; 23:893-913. https://doi.org/10.3109/03639049709148695

4. Kinget R, Kalala W, Vervoort L, Van Der Mooter G. Colonic drug targeting. J Drug Target 1998; 6:129-49. https://doi.org/10.3109/10611869808997888

5. Niwa K, Takaya T, Morimoto T, Takada K. Preparation and evaluation of a time-controlled release capsule made of ethylcellulose for colon delivery of drugs. J Drug Target 1995; 3:83-9. https://doi.org/10.3109/10611869509059209

6. Chourasia MK, Jain SK. Pharmaceutical approaches to colon targeted drug delivery systems. J Pharm Pharm Sci 2003; 6:33-66.

7. Mura P, Maestrelli F, Cirri M, González Rodríguez ML, Rabasco Alvarez AM. Development of enteric-coated pectin-based matrix tablets for colonic delivery of theophylline. J Drug Target 2003; 11:365-71. https://doi.org/10.1080/10611860310001639130

8. Asghar LF, Azeemuddin M, Jain V, Chandran S. Design and in vitro evaluation of formulations with $\mathrm{pH}$ and transit time controlled sigmoidal release profile for colon-specific delivery. Drug Deliv 2009; 16:205-13.

https://doi.org/10.1080/10717540902823960
9. Hu Z, Shimokawa T, Ohno T, Kimura G, Mawatari SS, Kamitsuna M, et al. Characterization of norfloxacine release from tablet coated with a new pH-sensitive polymer, P-4135F. J Drug Target 1999; 7:223-32. https://doi.org/10.3109/10611869909085505

10. Qi M, Wang P, Wu D. A novel pH- and time-dependent system for colonic drug delivery. Drug Dev Ind Pharm 2003; 29:661-7. https://doi.org/10.1081/DDC-120021315

11. Tugcu-Demiroz F, Acarturk F, Takka S, Konus-Boyunaga O. In vitro and in-vivo evaluation of mesalazine-guar gum matrix tablets for colonic drug delivery. J Drug Target 2004; 12 (2):105112. https://doi.org/10.1080/10611860410001693751

12. Hovgaard L, Brondsted H. Current applications of polysaccharides in colon targeting. Crit Rev Ther Drug Carrier Syst 1996; 13:185-223.

https://doi.org/10.1615/CritRevTherDrugCarrierSyst.v13.i34.10

13. Vandamme F, Lenourry A, Charrueau C, Chaumeil J-C. The use of polysaccharides to target drugs to the colon. Carbohydr Polym 2002; 48:219-231. https://doi.org/10.1016/S01448617(01)00263-6

14. Yu K, Wong D, Friend JD. Guar gum In: Florey, A.T., ed., Analytical Profiles of Drug Substances and Excipients (Academic Press, New York), 1998; Vol. 24, pp 245-276

15. Sinha VR, Kumria R. Polysaccharides in colon-specific drug delivery. Int J Pharm 2001; 224:19-38. https://doi.org/10.1016/S0378-5173(01)00720-7

16. Khan MZ, Stedul HP, Kurjaković N. A pH-dependent colontargeted oral drug delivery system using methacrylic acid copolymers. II. Manipulation of drug release using Eudragit L100 and Eudragit S100 combinations. Drug Dev Ind Pharm 2000; 26:549-54. https://doi.org/10.1081/DDC-100101266

17. Asghar LF, Chandran S. Design and evaluation of matrices of Eudragit with polycarbophil and carbopol for colon-specific delivery. J Drug Target 2008; 16:741-57. https://doi.org/10.1080/10611860802473345

18. Prakash A, Markham A. Oral delayed-release mesalazine. Drugs 1999; 57: 383-408. https://doi.org/10.2165/00003495199957030-00013

19. Steed KP, Hooper G, Monti N, Strolin Benedetti M, Fornasini G, Wilding IR. The use of pharmacoscintigraphy to focus the development strategy for a novel 5-ASA colon targeting system (TIME CLOCKw system), J Control Release 1997; 49:115-122. https://doi.org/10.1016/S0168-3659(97)00062-X

20. Sinko PJ. Physical Pharmacy and Pharmaceutical Sciences, Lippincott Williams and Wilkins, 5th Edition, 2006.

21. Chein YW. Novel Drug Delivery Systems, Marcel Dekker, INC, 2nd edition, 1992, 140 .

22. Gautam SP, Rai JP, Billshaiya U, Jain N, Vikram P, Jain DK. Formulation and evaluation of mouth dissolving tablet of loperamide. Int J Pharm Sci Res. 2013; 4(5): 1782-1788.

23. Patel P, Rai JP, Jain DK, Banweer J. Formulation, development and evaluation of cefaclor extended release matrix tablet. Int J Pharm Pharm Sci 2012; 4(4):355-357.

24. Pandey SP, Khan MA, Dhote V, Dhote K, Jain DK. Formulation development of sustained release matrix tablet containing metformin hydrochloride and study of various factors affecting dissolution rate. Sch Acad J Pharm 2019; 8 (3):57-73.

25. Jain P, Nair S, Jain N, Jain DK, Jain S. Formulation and evaluation of solid dispersion of lomefloxacin hydrochloride. Int J Res Pharm Sci 2012; 3(4):604-608. 